\title{
Qualia-Based Lexical Knowledge for the Disambiguation of the Japanese Postposition No
}

\author{
Sumiyo Nishiguchi \\ Osaka University \\ u301192b@ecs.cmc.osaka-u.ac.jp
}

\section{Introduction}

This paper proposes the elaboration of the qualia structure of the Generative Lexicon in [5] and the Extended Generative Lexicon theory [3]. My proposal is based on the Japanese genitive postposition no. The Japanese " $\mathrm{NP}_{1}$-no $\mathrm{NP}_{2}$ " construction expresses a wider range of relations between two entities than does the English possessive " $\mathrm{NP}_{1}$ 's $\mathrm{NP}_{2}$," such that the Pustejovskian qualia roles encoded in $\mathrm{NP}_{2}$ do not supply the necessary relations between two entities, which [7] succeeded to certain degree. Possessive relation disambiguation requires enriching lexical entries by incorporating the HAVE relation into the CONSTITUTIVE role and listing other qualia such as the ACTIVITY and the SPATIO-TEMPORAL role with the subcategories of LOCATION and TIME.

\section{Various Relations and Argument Reversal}

The Japanese genitive marker is semantically very ambiguous. 'NP1-GEN NP2' expresses not only possession as in John's pen and a part-whole relation as in John's leg, but also location, accompaniment, property, quantity, etc., as shown in Table 1.

\begin{tabular}{|c||c|c|c|c|}
\hline Relation & $\begin{array}{c}\text { Japanese } \\
\text { Possessive }\end{array}$ & $\begin{array}{c}\text { English } \\
\text { Possessive }\end{array}$ & $\begin{array}{c}\text { English } \\
\text { Compound }\end{array}$ & $\begin{array}{c}\text { English } \\
\text { PP }\end{array}$ \\
\hline \hline I possession & Tanaka-no kaban & Tanaka's bag & *Tanaka bag & a bag of Tanaka \\
\hline II part-whole & Tanaka-no kao & Tanaka's face & *Tanaka face & the face of Tanaka \\
\hline III location & Tokyo-no & *Tokyo's & Tokyo & $\begin{array}{c}\text { relatives } \\
\text { in Tokyo }\end{array}$ \\
& shinseki & relative & relatives & park at 3 o'clock \\
\hline IV time & 3-ji-no koen & $* 3$ o'clock's park & ${ }^{*} 3$ o'clock park & ork \\
\hline
\end{tabular}




\begin{tabular}{|c|c|c|c|c|}
\hline $\begin{array}{c}\mathrm{V} \\
\text { accompaniment }\end{array}$ & $\begin{array}{l}\text { kaban-no hito } \\
\text { boshi-no fujin }\end{array}$ & $\begin{array}{l}\text { *bag's man } \\
\text { *hat's lady }\end{array}$ & $\begin{array}{l}\text { the bag man } \\
\text { hat lady }\end{array}$ & $\begin{array}{c}\text { the man } \\
\text { with a bag } \\
\text { the lady with a hat }\end{array}$ \\
\hline VI trade & Kaban-no Sanpei & *bags' Sanpei & Bags Sanpei & Sanpei of Bags \\
\hline VII activity & $\begin{array}{l}\text { maaruboro-no } \\
\text { kuni } \\
\text { biiru-no machi }\end{array}$ & $\begin{array}{l}\text { *Marlboro's } \\
\text { country } \\
\text { *the beer's city }\end{array}$ & $\begin{array}{c}\text { Marlboro } \\
\text { country } \\
\text { *the beer city }\end{array}$ & $\begin{array}{l}\text { the country } \\
\text { of Marlboro } \\
\text { the city of beer }\end{array}$ \\
\hline VIII property & $\begin{array}{l}\text { chisee-no } \\
\text { hito } \\
\text { osu-no tora } \\
\\
\text { aoi-me-no } \\
\text { ningyo }\end{array}$ & $\begin{array}{l}\text { *intelligence's } \\
\text { man } \\
\text { *male's tiger } \\
\text { *blue eyes' doll }\end{array}$ & $\begin{array}{l}\text { *intelligence } \\
\text { man } \\
\text { a male tiger } \\
\text { blue eyes doll }\end{array}$ & $\begin{array}{c}\text { a man of } \\
\text { intelligence } \\
\text { a tiger of } \\
\text { male kind } \\
\text { the doll } \\
\text { with blue eyes }\end{array}$ \\
\hline IX weight & $\begin{array}{l}\text { 1-kiro-no } \\
\text { pasokon }\end{array}$ & $\begin{array}{l}* 1 \text { kg's } \\
\text { computer }\end{array}$ & $\begin{array}{c}1 \mathrm{~kg} \\
\text { computer }\end{array}$ & $\begin{array}{c}\text { the computer } \\
\text { with } 1 \mathrm{~kg}\end{array}$ \\
\hline $\mathrm{X}$ quantity & 3-bon-no pen & *three's pen & three pens & \\
\hline $\begin{array}{c}\text { XI } \\
\text { intensional } \\
\text { property }\end{array}$ & $\begin{array}{c}\text { nise-no fukahire } \\
\text { nise-no } \\
\text { keisatsukan }\end{array}$ & $\begin{array}{c}\text { *fake's shark fin } \\
\text { *fake's } \\
\text { police officer }\end{array}$ & $\begin{array}{l}\text { fake shark fin } \\
\text { fake } \\
\text { police officer }\end{array}$ & \\
\hline
\end{tabular}

Table 1:

Note the reversal of the possessor argument between (I) and (V-VI). The possessor argument is $\mathrm{NP}_{1}$ in (I), as in English Tanaka's bag whose possessor argument is Tanaka. On the contrary in $(\mathrm{V})$, the possessor of the bag is $\mathrm{NP}_{2}$ hito "man" and there is no English equivalent big bag's person. In (VI) Kaban-no Sanpei "Bags Sanpei," Sanpei is a bag store, and therefore the possessor of a bag. The controller-controllee relation is also reversed, for example, in Tanaka-no kuruma "Tanaka's car" (type I), Tanaka is the controller of the car, i.e., $\mathrm{NP}_{2}$ the car is at Tanaka's disposal as in English the girl's car [7]. On the contrary, in boshi-no fujin "the lady with a hat," $\mathrm{NP}_{1}$ boshi is at the person's disposal. Aoi-me-no ningyo "the doll with blue eyes," literally, "blue eyes' doll" in (VIII) even expresses the part-whole relation in the reverse direction, compared with ningyo-no me "the doll's eyes." Such non-canonical relations, i.e., other than those expressing possession or a part-whole relation, are more likely expressed in noun compounds such as magic land or prepositional phrases using of, in, or with in English.

\section{Problems with Deriving Various Possessive Re- lations from $\mathrm{NP}_{2}$}

Possessive relations are ambiguous in both English and Japanese. For example, there is more than one interpretation for Tanaka-no hon "Tanaka's book." Tanaka's book may refer to the book that Tanaka owns or the book 
that Tanaka wrote $[1,87]$. In view of such ambiguity, [4] assumes two syntactic types for John's depending on whether or not the following noun is inherently relational. If the following noun is a non-relational common noun (CN) such as car, John's composes with car which is regular (et) type, and the relation between John and car is contextually supplied (1a). On the contrary, when John is followed by inherently relational nouns such as brother, employee and enemy, which are (e,et) type with an extra argument slot, the relation between John and his brother in John's brother inherits kinship from the two-place predicate brother (1b). (2) exemplifies the computation related to another relational noun, friend.

(1) a. Free R type:

Syntax: [John's $]_{N P / C N}$

Semantics: $\lambda Q \lambda P\left[N P^{\prime}(\lambda z[\exists x[\forall y[[Q(y) \wedge R(y)(z)] \leftrightarrow y=x] \wedge\right.$ $P(x)]])]$

b. Inherent relation type:

Syntax: [John's $]_{N P / T C N}$ (TCN: transitive common noun)

Semantics: $\lambda R \lambda P\left[N P^{\prime}(\lambda z[\exists x[\forall y[R(z)(y) \leftrightarrow y=x] \wedge P(x)]])\right]$

(2) Syntax: $\left[[\text { John's }]_{N P / T C N}[\text { friend }]_{T C N}\right]_{N P}$

Semantics: $\lambda R \lambda P\left[J_{o h n}(\lambda z . \exists x[\forall y[R(z)(y) \leftrightarrow y=x] \wedge P(x)]](\right.$ friend$\left.o f^{\prime}\right)=\lambda P\left[J_{o h n}^{\prime} s\left(\lambda z . \exists x\left[\forall y\left[\right.\right.\right.\right.$ friend $\left.\left.\left.-o f^{\prime}(z)(y) \leftrightarrow y=x\right] \wedge P(x)\right]\right]$

If we apply Partee's theory to Japanese examples, most of the possessive relations are unpredictable, and the contextually supplied relation $\mathrm{R}$ remains largely ambiguous. Possession relation (I) is prototypical, and part-whole relation (II) can be derived lexically from a possessive te "hand" [1]. However, other possessee nominals are not necessarily relational. In order to reduce the cost of pragmatics, [7] apply the Qualia Structure [5] of the possessee noun and type-shift even non-inherently relational $\mathrm{NP}_{2}$ into a relational noun. For example, even though poem is not a relational noun, John's poem can be interpreted as the poem that John composed because the internal semantic structure of poem contains an author-of relation as AGENTIVE role. The meaning shifting operator $\mathrm{Q}_{A}$ raises a one-place holder poem in (3a) into a two-place holder in (3b). The type-shifted $\mathrm{NP}_{2}$ can now combine with the possessive NP, which has a uniformly type ((e,et),(et,t)) so that the authorship relation is inherited from $\mathrm{NP}_{2}$ poem, and $\mathrm{R}$ is no longer a free variable. 


$$
\mathrm{Q}_{A}(\mathrm{poem})=\lambda x \lambda y\left[\text { poem }^{\prime}(x) \wedge \operatorname{compose}^{\prime}(x)(y)\right]
$$

However, even [7]'s method is not sufficient to systematically compute the meaning of the Japanese ' $\mathrm{NP}_{1}$-no $\mathrm{NP}_{2}$ ' construction. For example, in terms of location (III), tomodachi "friend" and shinseki "relative" in Tokyono tomodachi "a friend in Tokyo" and Kyoto-no shinseki "Kyoto relative" are relational nouns, i.e., friend-of $x /$ relative- of $x$, but the relation between $\mathrm{NP}_{1}$ and $\mathrm{NP}_{2}$ is not friend-of or relative of but of location, namely, $\mathrm{NP}_{2}$ is in $\mathrm{NP}_{1}$. We also encounter a problem with boshi-no fujin "the lady with a hat." Since wearing a hat is not part of the qualia roles, that are AGENTIVE (origin), TELIC (purpose), CONSTITUTIVE (part-whole) and FORMAL (isa) roles, of the non-inherently relational noun fujin "lady," even Vikner and Jensen's system is unable to supply the binder for R.

\section{Enriching the Qualia Structure}

In order to reduce the weight of pragmatics, I propose encoding more information into the lexicon elaborating the qualia structure. Specifically, I suggest adding two qualia into the already existing four qualia roles:

- CONSTITUTIVE = SIZE, WEIGHT, HAVE, COLOR

- TELIC $=$ TRADE

- SPATIO-TEMPO = IN, AT

- ACTIVITY = MAKE_ACT, DRINK_ACT

HAVE, which is a two-place predicate with possessor and possessee arguments, is added to subcategories of the extended CONST quole. LOCATION and TIME are subcategories of the new SPATIO-TEMPO role. These are added to the qualia roles of nominals because all physical objects usually occupy some space and time [6]. In addition to WEIGHT, which is included into the CONST quale in [5], we add SIZE, which is related to dimensionality, and COLOR. TRADE is incorporated into the TELIC role.

SIZE and COLOR are part of the CONST role of clothing artifacts such as boshi "hat"; therefore, aka-no boshi "the red hat" can be computed compositionally. The TIME, the LOCATION and the HAVE roles of location terms such as koen "park" are used to interpret haru-no koen meaning "the park in spring," chicaku-no koen meaning "a nearby park," and tsutsujino koen meaning "a park with azaleas," respectively. TRADE role in the TELIC of proper nouns is observed in Supa-no Maruetsu "Maruetsu Supermarket" and Kaban-no Sanpei "Sanpei for bags." Such expanded qualia roles can substitute $\mathrm{R}$ through type-shifting $\mathrm{NP}_{2}$. 
The $\epsilon$ operator and the $\iota$ operator lower the types of $\mathrm{CN}$ into (e). The use of the $\epsilon$ operator follows its use for Japanese nouns in [2].

(4) boshi "hat": $\epsilon x \cdot h a t^{\prime}(x)$ : some x satisfying hat'(x), if there is one hito "person": ıy.person'(y): the unique $\mathrm{x}$ satisfying person'(x), if there is such a thing

no: $\lambda X . \lambda Y . \iota y .[Y(y) \wedge R-Y(\epsilon x . X(x))(y)]$

boshi-no hito "the hat person": $\iota y .\left[\right.$ person' $\left.^{\prime}(y) \wedge H A V E\left(\epsilon x . h a t^{\prime}(x)\right)(y)\right]$

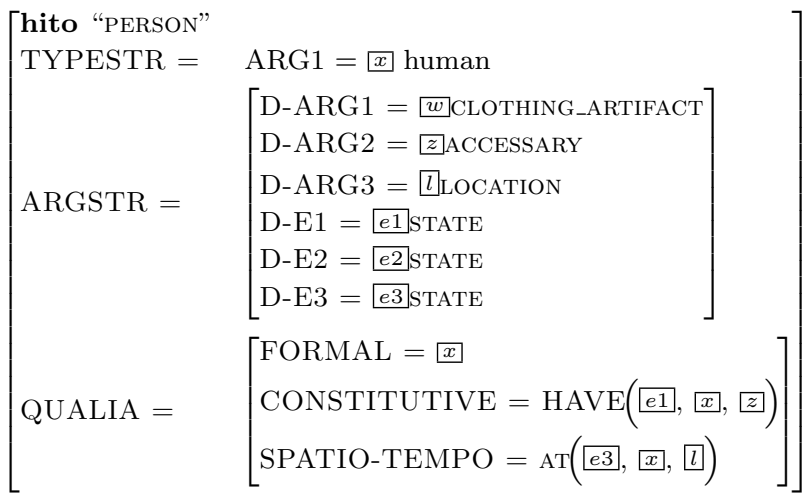

The SPATIO-TEMPO role of nouns enables the interpretations for Tokyono shinseki "Tokyo relative" and 3-ji no koen "the park at three o'clock," by supplying location and temporal relations.

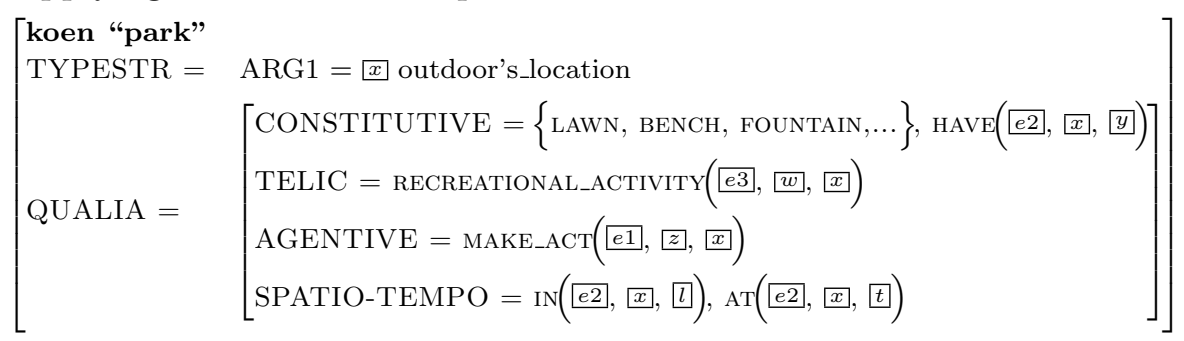

The ACTIVITY roles in Maarumoro-no kuni "the Marlboro Country," and biiru-no machi, or "the city of beer" account for the interpretations.

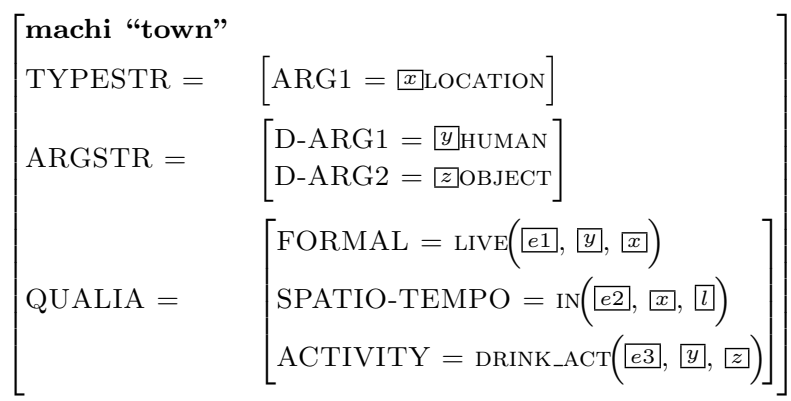




\section{Conclusion}

Japanese genitive postpositions cannot be disambiguated in terms of the existing qualia of the possessee nominals. We need to enrich the lexical input by expanding the subcategories of FORMAL and CONSTITUTIVE roles, and by supplementing them with new roles - SPATIO-TEMPO and ACTIVITY. As [7] did not propose any method for restricting the quale to be used for type-shifting, the present analysis does not provide any suggestions for identifying the quale to be used for the interpretation of the possessive noun phrases. However, it provides the enriched lexical entry which enables access to the sense of $\mathrm{NP}_{2}$ and determines the semantic relation expressed by Japanese genitive postpositions.

\section{References}

[1] Chris Barker. Possessive Descriptions. CSLI Publications, Stanford, 1995.

[2] Ronnie Cann, Ruth Kempson, and Lutz Marten. The Dynamics of Language: an Introduction, volume 35 of Syntax and Semantics. Academic Press, Amsterdam, San Diego, 2005.

[3] Alessandro Lenci, Nuria Bel, Federica Busa, Nicoletta Calzolari, Elisabetta Gola, Monica Monachini, Antoine Ogonowski, Ivonne Peters, Wim Peters, Nilda Ruimy, Marta Villegas, and Antonio Zampollo. Simple: A general framework for the development of multilingual lexicons. International Journal of Lexicography, 13:4:249-263, 2000.

[4] Barbara H. Partee. Genitives - a case study. appendix to theo m.v.janssen, "compositionality". In Handbook of Logic and Language, pages 464-470. Elsevier Science Publishers, Amsterdam, 1983, 1997.

[5] James Pustejovsky. The Generative Lexicon. MIT Press, Cambridge, 1995.

[6] John F. Sowa. Knowledge Representation: Logical, Philosophical, and Computational Foundations. Course Technology, 1999.

[7] Carl Vikner and Per Anker Jensen. A semantic analysis of the english genitive. interaction of lexical and formal semantics. Studia Linguistica, 56:191-226, 2002. 